\title{
UNUSUAL CASE OF RESPIRATORY OBSTRUCTION DURING INDUCTION OF ANAESTHESIA
}

\author{
A.R. RAMACHANDRA REDDY, B.SC., M.B.B.S., C.R.C.P.(c)
}

Thrs REPORT CONCERNS an unusual case of respiratory obstruction during induction of anaesthesia, caused by a tumour of the laryngeal inlet.

An 18-month-old child weighing $8.3 \mathrm{~kg}$ was admitted for elective removal of a hydrocoele and repair of an inguinal hernia. The child had a personal history of congenital depressed chest, von Recklinghausen's disease, vomiting and failure to gain weight. Apart from a maternal history of von Recklinghausen's disease with neurofibromata there was nothing contributory in the family history. Stools were loose and respiration noisy.

On systemic examination cafe-au-lait spots were noted and there was pectus cavus with indrawing of the intercostal and subcostal spaces; otherwise no abnormality was noted. There was hydrocoele of the cord on the right side.

Laboratory examinations: bicarbonate $16 \mathrm{mEq} / \mathrm{L}$, chloride $102 \mathrm{mEq} / \mathrm{L}$, potassium $5.1 \mathrm{mEq} / \mathrm{L}$, sodium $142 \mathrm{mEq} / \mathrm{L}$ and $\mathrm{Hgb}$. $12.3 \mathrm{gm} / 100 \mathrm{ml}$. Chest $\mathrm{x}$-ray showed pectus excavatum. There were no other abnormalities of the soft tissues.

The patient was booked for a right hydrocoelectomy but this was postponed because of croup developed on the previous day. The next day he was examined for respiratory infection, as he had croup early in the morning. The chest was clear to auscultation. A chest $\mathrm{x}$-ray done after the examination did not reveal any abnormality. He was pre-medicated with morphine $0.5 \mathrm{mg}$ and hyosine $0.05 \mathrm{mg}$ one hour preoperatively. On arrival in the operating room the patient had obstructed breathing without apparent cause.

A Montreal infant set was used to put the patient to sleep. After two minutes he became cyanotic. After culting off all the anaesthetics except for oxygen, the patient became pink, and as there was no apparent obstruction another attempt was made to induce anaesthesia. Again there was cyanosis with respiratory obstruction. At this stage laryngoscopy was done. A mass was visualized posterior to the arytenoids but covering the posterior half of the laryngeal opening (Figure 1). At first it was difficult to identify the cords. An 18-gauge Portex tube was passed into the trachea and it was suggested that the surgeon perform a tracheostomy to provide a reliable airway. An emergency tracheostomy was done the same day. An x-ray of the neck showed a soft tissue nodule in the region of the vocal cords and a barium swallow was done to localize the tumour (Figures 2,3 ).

A week later the child was taken back to the operating room to excise the tumour through the mouth. This was abandoned as it was difficult to excise through a suspension laryngoscope. At this time a biopsy was done and the pathology report indicated a polypoid mass covered by polarized laryngeal type squamous epithelium. A plexiform neuroma was present in the stroma.

-Department of Anaesthesia, Children's Hospital, Vancouver, B.C. 
REDDY: RESPLIATOIY OESTRUCTION DURING INDUCTION OF ANAESTHESIA 193

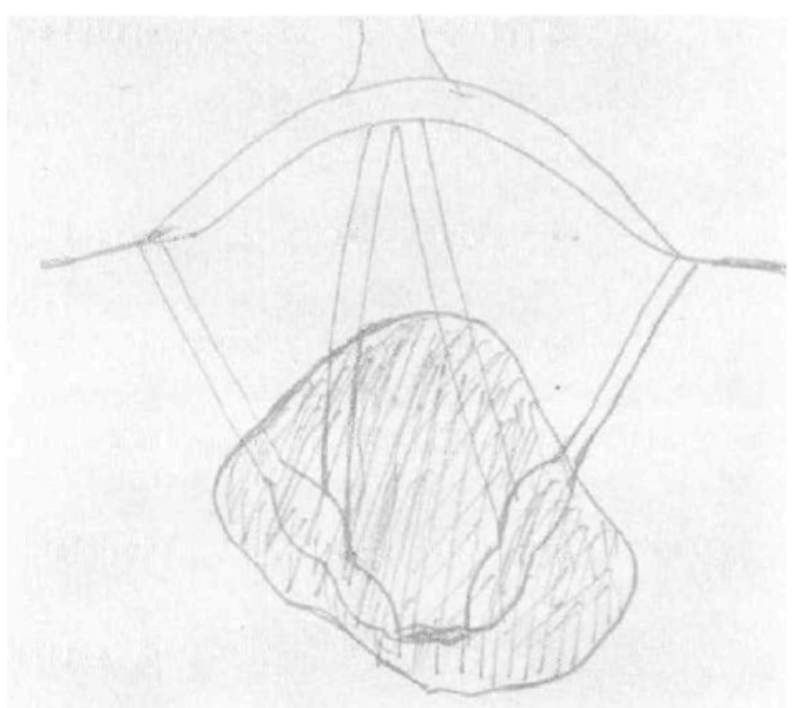

Froune I

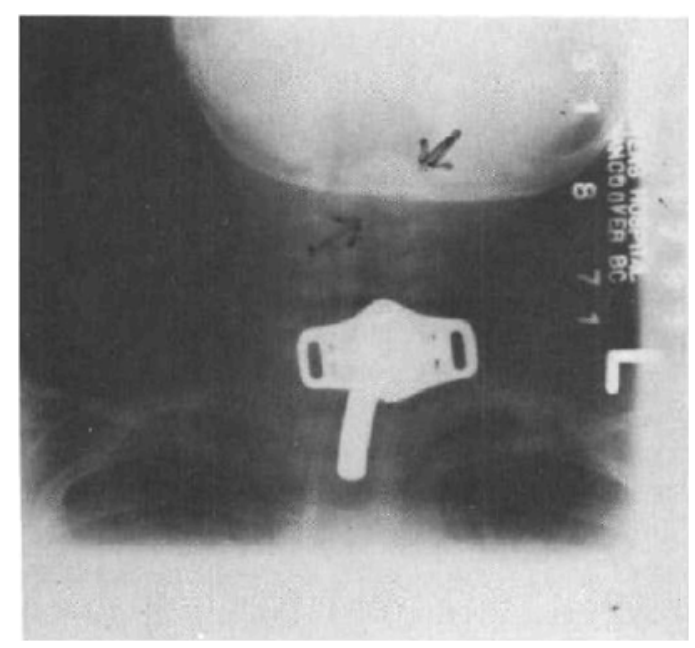

Figune 2 


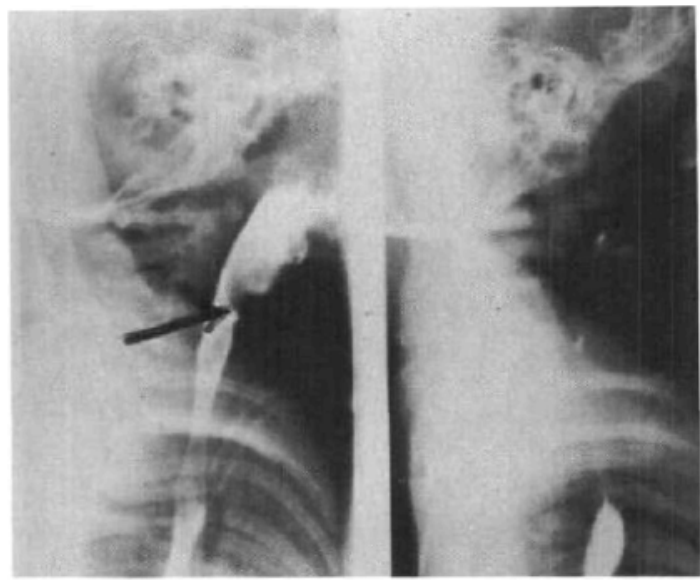

Ficure 3

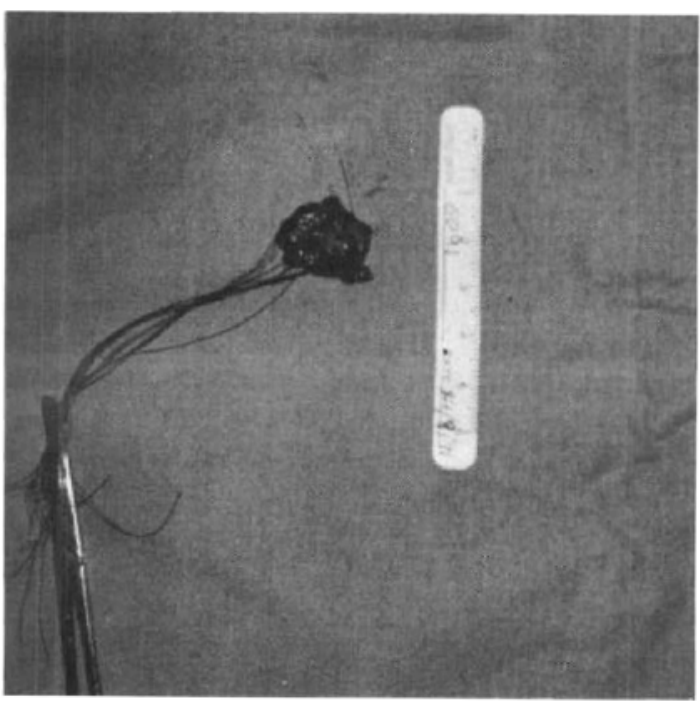

Figuhe 4

On September 24, 1971 the patient was retumed to the operating room for excision of the tumour. Premedication was morphine $0.5 \mathrm{mg}$, byoscine $0.05 \mathrm{mg}$ one hour preoperatively A metal tracheotomy tube was inserted after an unsuccessful attempt to keep the $20 \mathrm{~F}$ gauge flexometallic tube in the tracheostomy. A transverse incision was made in the neck over the hyoid bone. Thyrohyoid membrane was exposed and divided, entering the pre-epiglottic space. The epiglottis was separated from the base of the tongue in the vallecula and was retracted inferiorly. The tumour was identified in the pharynx and was found to be entirely supraglottic in location and appeared to be infiltrating from the lateral pharyngeal wall and extending on to the aryepiglottic fold on the left (Figure 4). There were three or 
FEDDY; RESPIRATOHY OBSTRUCTION DURING INDUCTION OF ANAESTHESIA

four large plexiform neuromatous bands extending into deeper tissues of the lateral part of the neck which were traced as far laterally as was feasible through the exposure. The pharynx was closed in two layers.

A gastrostomy was performed at the same time as a palliative measure for feeding.

\section{Discussion}

Tumours of the larynx are not uncommon and several different types of tumours are described in the literature. Fibrolipoma ${ }^{1}$ papilloma, chondroma and haemangioma, ${ }^{2}$ lipoma, ${ }^{3}$ fibrolipoma, neurofibroma ${ }^{5,8}$ have been reported. Neurofibroma arising from the aryepiglottic fold has been described. ${ }^{7}$

The present case is similar to those described by Hoover ${ }^{2}$ and by Goonewardene, ${ }^{7}$ overlying the upper aperture of the larynx posteriorly. The presence of recurrent croup, deformity of the chest and vomiting in this youngster should have directed attention to the possibility of an obstruction at the level of the glottis.

With the history of von Recklinghausen's disease in the family it is wise to look for the possibility of neurofibromata of the larynx. ${ }^{2}$

Symptoms referrable to laryngeal obstruction are dyspnoea, stridor, wheezing, hoarseness and aphonia. The dyspnoea of laryngeal obstruction is associated with deep inspiration, indrawing of the suprasternal notch and supraclavicular, inter. costal and subcostal spaces. The stridor of laryngeal disease occurs in the inspiratory phase in contrast to the wheezing of asthma and other bronchiolitic disturbances which is predominantly in the expiratory phase. With the severe inspiratory retractions the deformity of the thorax may be obvious (Figures 5,6 ). As in this patient, severe dyspnoea is frequently associated with difficulty in nursing so that undernutrition is common. Cyanosis is rare and respiratory infections tend to exaggerate all the symptoms.

Other congenital abnormalities may also present as persisting stridor after a few days of life ${ }^{8}$ The most common are congenital deformity or flabbiness of the epiglottis, laryngomalacia, mucous retention cysts, branchial cleft cysts, and thyroglossal duct remnants.

Plexiform neuromata may be localized to an area (facial gigantism), to an organ (stomach, urinary bladder), to the laryngeal wall as in this particular case attached to a branch of a cranial nerve, or may be disseminated and attached as soft tissue tumours to peripheral nerves. Plexiform neuromata are well differentiated hypertrophied peripheral nerve filaments resembling a tangle of spaghetti. They appear to be distinct from neurofibromata. There is some obscurity between the disseminated neuromata and disseminated neurofibromatosis of von Recklinghausen's disease. There is striking histological diversity and obvious difference in lineage and such tumours are commonly described as varieties of the same order of lesion. ${ }^{\theta}$

\section{SUMMARY}

A plexiform neuroma of the left ary-epiglottic fold and arytenoids caused respiratory obstruction during induction of anaesthesia in an 18-month-old child. The tumour was responsible for frequent attacks of croup, failure to grow and ana- 


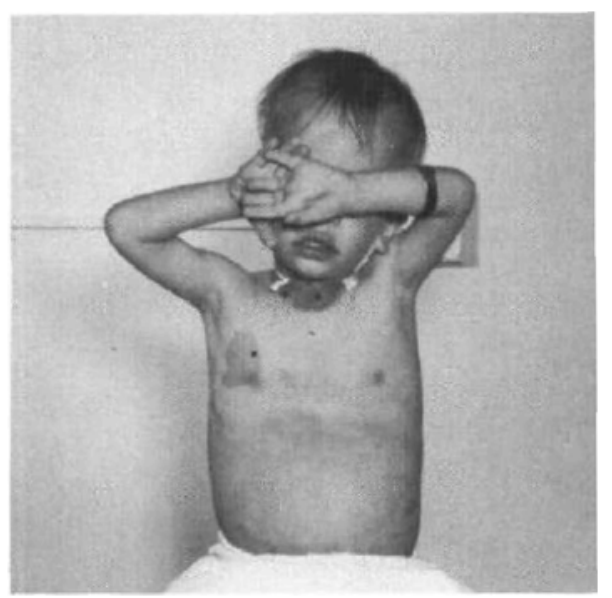

Figuge 5

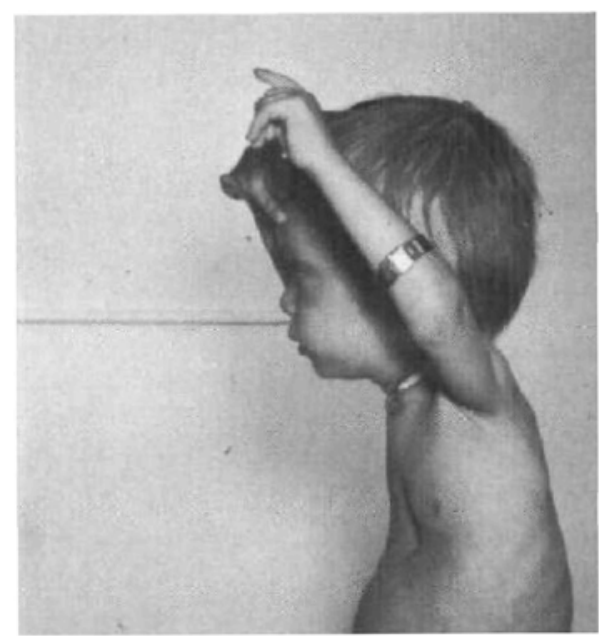

FiGURe 6

tomical deformity of the chest. The tumour was diagnosed during an attempt to intubate for hydrocoelectomy and right inguinal hernia repair:

\section{ACKNOWLEDGMENTS}

I wish to thank Doctors W.J. Patterson and R.H. Marshall for permission to publish this case, Mrs Kennedy for secretarial help and Mr Ron Valliers for photog. raphy.

\section{RÉSUMÉ}

Un neurome plexiforme du pli ary-épiglottique et des arytenoides gauches a cause une obstruction respiratoire au cours de l'induction de lanesthésie chez un enfant agé de 18 mois. 
REDDY: RESPIRATORY OBSTRUCTION DURLNG INDUCTION OF ANAESTHESLA

La tumeur avait causé de fréquentes attaques de croup, un retard de développement et une déformation anatomique du thorax. On a fait le diagnostic de cette tumeur en tentant de pratiquer une intubation trachéale chez cet enfant que l'on opérait pour une cure d'hydrocèle et une cure de hernie inguinale droite.

\section{REFERENCES}

I. New, G.A. Fibrolipoma of larynx. J.A,M,A, 60:566 (1916).

2. Hooven, W.B. Benign tanours of the Jarynx, Their diagnosis and treatment Surgical Clinics of North America, 20; 697 (1940)

3. Macinie, A.C. Lipoma of the larynx, Larygotol., 65: 426 (1951).

4. Frat, F,A. Srark, D.E. Neurofibroma of the larynx (Case Reports), Laryngoscope (St Louis) 63: 652 (1953).

5. Drxon, J.W. Solitary neurolemmona. Laryngotol, 73: 819,1959)

6. KRaGH, L.W. Soule, E.H.; Masson, J.K. Benign and malignant Neurolemmomas of Head and Neck, Surg. Gyn. Obstet., II I: 21 1 (1960).

7. Goonewardene, T.W. Respiratory Obstruction following Anaesthesia, Brit. J. Anaesth., 39: 983 (1967),

8. Netson, W.E. Textbook of Pediatries, Philadelphia, W.B. Saunders, 9th ed., 1969, page 901 .

9. Andenson, W.A.D. Textbonk of Pathology, St. Louis, C.V. Mosby, and ed, 1953, page 1306 . 